that among patients in this institution the $\mathrm{HBs} A \mathrm{~g}$ carrier state is not benign and is probably associated with a high level of infectivity and chronic liver disease.

Among staff the prevalence of HBsAg was low, although higher than in the general population, eAg was not found, and clinically overt hepatitis B was rare. Nevertheless, half the nursing staff who had served for 10 years or longer had antiHBs. This suggests that active immunity is acquired with little clinically overt disease. There is therefore no indication for routine passive prophylaxis, but should safe and simple active immunisation become available this should be recommended in such "at-risk" groups. In the event of needle-stick accidents or exposure to similar "extra risks" hepatitis B immune globulin should be given.

We thank G D Searle and Co, High Wycombe, Bucks, for financial support and technical help, and Mr B Cohen, of PHLS, Colindale Avenue, London NW9, for kindly supplying HBcAg for the anti-HBc assay.

\section{References}

${ }^{1}$ Kingham, J G C, et al, Gut, 1978, 19, 91.

2 Blumberg, B S, et al, Annals of Internal Medicine, 1967, 66, 924.

${ }^{3}$ Hollinger, F B, et al, American fournal of Epidemiology, 1972, 95, 356.

4 Szmuness, W, et al, fournal of Infectious Diseases, 1972, 126, 498

${ }^{5}$ Goodman, M, et al, Pediatrics, 1971, 48, 907.

${ }^{6}$ Szmuness, W, Pick, R, and Prince, A M, American fournal of Epidemiology, $1970,92,51$.

' Melartin, L, and Panelius, M, Annales Medicinae Experimentalis et Biologia Fenniae, 1967, 45, 157.

${ }^{8}$ Krugman, S, and Giles, J O, Fournal of the American Medical Association, 1970, 212, 1019.

${ }^{9}$ Sutnick, A I, et al, fournal of the American Medical Association, 1968, 205, 670.

${ }^{10}$ Hoofnagle, J H, et al, New England fournal of Medicine, 1974, 290, 1336.

${ }_{11}$ Magnius, L O, and Espmark, J A, Fournal of Immunology, 1972, 160, 1017.

12 Magnius, L O, Lindholm, A, and Lundin, P, fournal of the American Medical Association, 1975, 231, 356.

13 Eleftheriou, N, et al, Lancet, 1975, 2, 1171.

${ }^{14}$ Feinmann, S V, et al, Lancet, 1975, 2, 1173.

15 Nielsen, J O, Dietrichson, O, and Juhl, E, Lancet, 1974, 2, 913.

(Accepted 27 fune 1978)

\title{
Home blood sampling for plasma glucose assay in control of diabetes
}

\author{
S HOWE-DAVIES, R R HOLMAN, M PHILLIPS, R C TURNER
}

British Medical fournal, 1978, 2, 596-598

\section{Summary and conclusions}

Estimation of plasma glucose in home blood samples is needed to improve diabetic control. Sufficiently precise measurements on capillary blood were obtained by (a) storing Reflotest glucose-oxidase strips in a desiccant container before reading and (b) collecting blood samples into a simple vacuum bottle containing potassium fluoride (assay of sodium content indicating volume of plasma collected). The precision of the methods ( \pm SD) was $0.35 \mathrm{mmol} / 1(-6.3 \mathrm{mg} / 100 \mathrm{ml})$. Clinical reliability was assessed by measuring the basal plasma glucose concentration at home on different mornings in patients with maturity-onset diabetes, the day-to-day variation (1 SD) being 0.73 and $\pm 0.92 \mathrm{mmol} / \mathrm{l}$ (13.2 and $\pm 16.6 \mathrm{mg} / 100 \mathrm{ml}$ ) respectively.

The mean basal plasma glucose concentration in all 84 patients with maturity-onset diabetes from three general practices was $8 \mathrm{mmol} / 1(144 \mathrm{mg} / 100 \mathrm{ml}), 44$ of the values exceeding $6 \mathrm{mmol} / 1(108 \mathrm{mg} / 100 \mathrm{ml})$. Improving control by monitoring the basal plasma glucose concentration in maturity-onset diabetes might help to prevent diabetic complications.

\footnotetext{
Department of the Regius Professor of Medicine, Radcliffe Infirmary, Oxford OX2 6HE

$S$ HOWE-DAVIES, BSC, DRCOG, research fellow

R R HOLMAN, MRCP, research fellow

$M$ PHILLIPS, MB, research fellow

R C TURNER, MD, FRCP, clinical reader
}

\section{Introduction}

Current treatment of diabetes does little to prevent complications, possibly because control based on urine glucose estimation is not precise enough. Improved control might be gained by regular measurement of the plasma glucose concentration at home. In maturity-onset diabetes a logical aim is to lower the basal plasma glucose concentration to normal, : while in insulin-dependent diabetes additional plasma glucose estimations after meals are needed to determine the requirement for insulin before meals. Although plasma glucose may be estimated at home by patients with glucose-oxidase strips and a colorimeter, ${ }^{3}{ }^{4}$ the need for equipment means that the method $i$ not widely applicable.

In this paper we examine alternative methods for home capillary blood sampling, including a stored glucose-oxidase strip and a new collector bottle. Their clinical use has been validated by fasting plasma glucose measurements in patients with maturity-onset diabetes.

\section{Methods}

Reflotest-The colour of Reflotest glucose (Boehringer Mannheim) remains stable when stored under suitable conditions (see Results). Patients prick their finger with an automatic lancet (Autolet; Owen Mumford, Woodstock, Oxon), apply a drop of blood on to a Reflotest strip, wait exactly 60 seconds, wipe off the blood, and send the strip in a desiccator container to hospital or general practice clinic for reading in a Reflomat colorimeter. Each strip is closely inspected and discarded if the colour is uneven, indicating that the single drop of blood has not been correctly applied.

Vacuum collector bottles-Small polyethylene bottles containing approximately $1.2 \mathrm{ml}$ Analar potassium fluoride $100 \mathrm{~g} / \mathrm{l}$ are sealed after being compressed to produce a partial vacuum. The bottle top, which is covered by a screw cap, contains a shallow depression. After pricking a finger the patient puts a drop of blood into the depression. He then pricks through the drop (with the lancet used to prick his finger) to make a small hole, and when the lancet is withdrawn the 
blood is automatically sucked into the container. The screw cap is replaced and the bottle sent to the laboratory. The sodium concentration (allowance being made for sodium in the Analar potassium fluoride) indicates the amount of plasma in the container, the plasma sodium concentration being taken as $140 \mathrm{mmol}(\mathrm{mEq}) / 1$. The sodium content of the collector fluid is measured in $100 \mu \mathrm{l}$ aliquots with a spectrophotometer. If the sodium content indicates that less than $10: 2 \mathrm{l}$ of blood is present insufficient blood has been taken for precise assay. The glucose concentration is assayed with glucose oxidase in 300 !l aliquots. To allow for the glucose content of the red cells diffusing into the collector fluid, the plasma glucose concentration is estimated by multiplying the collector fluid glucose content by 0.75 (a packed cell volume of $0.4\left(40^{\circ} \%\right.$ ), red cell glucose space of $60^{\circ}{ }_{0}{ }^{\circ}$ and sodium content of $8 \mathrm{mmol} / 1^{\circ}$ being assumed). If a patient is anaemic, with a packed cell volume of 0.3 , the plasma glucose concentration is underestimated by $11^{\circ}$, .

Other collectors-In a preliminary study patients were asked to collect blood into (1) simple capillary tubes coated with sodium fluoride, (2) capillary vessels with sodium fluoride that widen to collect blood (Sarstedt), (3) wide-mouthed $(0.8 \mathrm{~cm})$ tubes containing sodium fluoride into which blood could be "milked" from the finger (Sarstedt), and (4) capillary tubes supplied with a diluent container to which blood could be transferred (Unopettes; Becton Dickinson).

\section{CLINICAL STUDIES}

To assess the clinical reliability of the first two methods fasting blood samples were taken from all 84 patients with maturity-onse diabetes treated by diet or oral hypoglycaemic agents in three general practices. Their average age was 65 years. Seventy-two of them $\left(86^{\circ}{ }_{0}\right)$ had no glycosuria on routine testing. Morning clinics were held and patients were instructed to attend fasting. Venous blood was taken and put $(a)$ into a conventional sodium fluoride bottle for direct plasma glucose assay, $(b)$ into a collector bottle, and (c) on to a Reflotest strip, which was read precisely one minute after blood had been wiped off. The patients were asked to take capillary blood samples on three consecutive mornings at home after an overnight fast for both collector bottles and Reflotest strips, the strips then being kept in desiccator tubes (those in which Boehringer package Reflotest). Both samples were then either taken to the surgery or sent by post for later measurement.

Glucose concentration was measured with the manual Boehringer kit, and sodium concentration with a Unicam SP90a atomic absorption spectrophotometer. The precision of methods and day-to-day variation in patients with fasting plasma glucose concentrations below $8 \mathrm{mmol} / 1(144 \mathrm{mg} / 100 \mathrm{ml})$ were obtained from two values ( $\mathrm{SD}=$

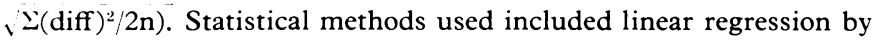
least-square analysis and the paired $t$ test.

\section{Results}

Reflotest-Blood samples were placed on Reflotest strips in the laboratory and read in the Reflomat meter over five days. After storage at $4^{\circ}, 20^{\circ}$, and $35^{\circ} \mathrm{C}$ in a desiccator the plasma glucose estimations fell appreciably only at the higher temperature and higher glucose concentrations (fig 1). When stored in a normal atmosphere there was a greater reduction. When the strips were left in $100^{\circ}{ }^{\circ}$ humidity the estimation was more dependent on temperature than on blood glucose concentration. Leaving the strips in sunlight deepened the colour. Thus for routine use the strips need to be transported in a light-proof container with desiccant. Fig 2 shows the stability of the mean of duplicate estimations on blood samples taken in a diabetic clinic and read at daily intervals for seven days after storage in desiccator tubes. Analysis of duplicates showed a precision of $\pm 0.25 \mathrm{mmol} / \mathrm{l}( \pm 4.5 \mathrm{mg}$ / $100 \mathrm{ml}$ ) at one minute, and on subsequent days this rose to \pm 0.35 $\mathrm{mmol} / \mathrm{l}( \pm 6.3 \mathrm{mg} / 100 \mathrm{ml})$. The accuracy was estimated by comparing results with direct plasma glucose assay. For values below $8 \mathrm{mmol} / \mathrm{l}$ $(144 \mathrm{mg} / 100 \mathrm{ml})$ the standard deviation of the difference between these estimations was $\pm 0.47 \mathrm{mmol} / 1 \quad( \pm 8.5 \mathrm{mg} / 100 \mathrm{ml}) \quad(\mathrm{n}=89$; mean $5.9 \mathrm{mmol} / \mathrm{l}-106 \mathrm{mg} / 100 \mathrm{ml}$ ), and for values above $8 \mathrm{mmol} / \mathrm{l}$, $\pm 0.85 \mathrm{mmol} / 1( \pm 15.3 \mathrm{mg} / 100 \mathrm{ml})(\mathrm{n}=56 ;$ mean $10.9 \mathrm{mmol} / \mathrm{l}-196$ $\mathrm{mg} / 100 \mathrm{ml}$ ).

Vacuum collector bottles-There was no difference in results from replicate blood aliquots assayed between five minutes and five days after addition to the collector bottles. Precision, estimated from duplicate samples, was $( \pm 1 \mathrm{SD}) \pm 0.31 \mathrm{mmol} / 1( \pm 5.6 \mathrm{mg} / 100 \mathrm{ml})$.

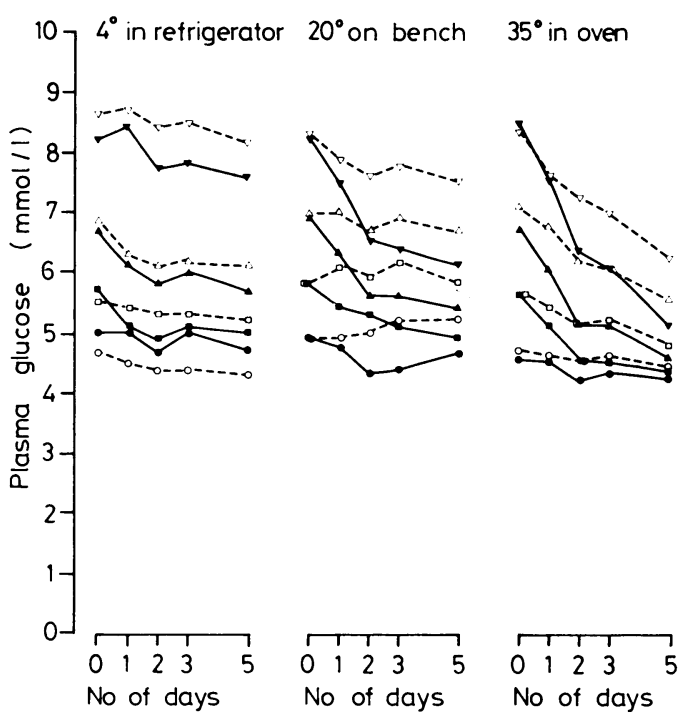

FIG 1-Stability of colour of Reflotest strips read at one minute in Reflomat meter (day 0 ) or stored at three different temperatures either in humid atmosphere (closed symbols) or desiccators (open symbols) before reading. Mean of triplicates of four different blood samples (A-D). In normal atmosphere, particularly at higher glucose concentrations, colour tended to fade and glucose estimation to fall, but there was little change when stored in desiccators.

Conversion: SI to traditional units-Plasma glucose : $1 \mathrm{mmol} / 1$ $\approx 18 \mathrm{mg} / 100 \mathrm{ml}$

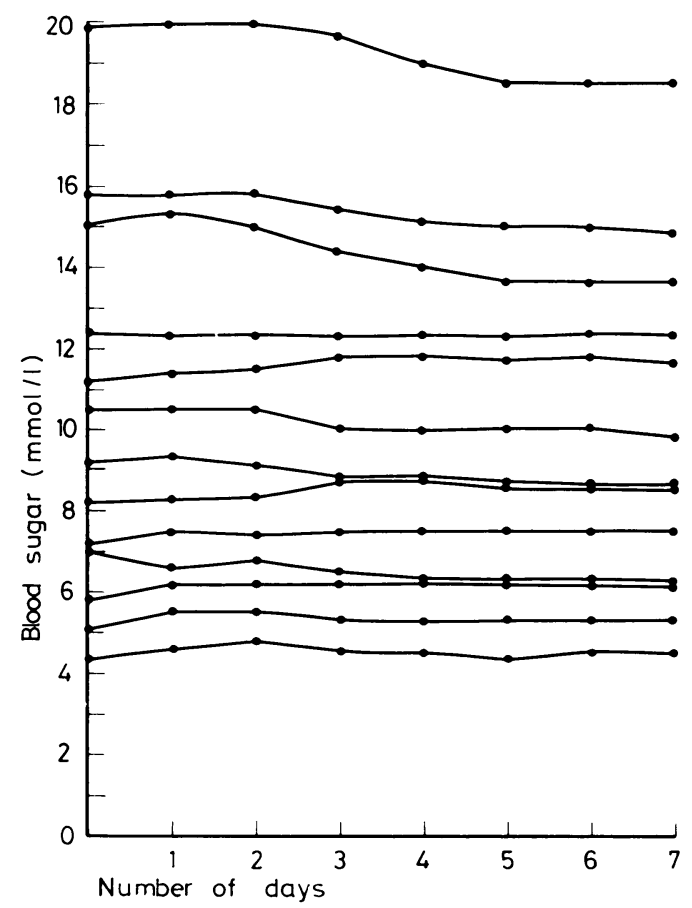

FIG 2-Means of duplicate estimations on 13 blood samples from diabetic patients read on Reflotest strips at one minute, and then stored in desiccator containers at room temperature and reread daily for one week. (Blood sugar: $1 \mathrm{mmol} / \mathrm{l} \approx 18 \mathrm{mg} / 100 \mathrm{ml}$.)

The accuracy was estimated by comparing the results with direct plasma glucose assay. For values below $8 \mathrm{mmol} / 1$ the standard deviation of the difference between these estimations was $\pm 0.61 \mathrm{mmol} / 1$ $( \pm 11.0 \mathrm{mg} / 100 \mathrm{ml}) \quad(\mathrm{n}=92 ;$ mean $5.7 \mathrm{mmol} / \mathrm{l}-103 \mathrm{mg} / 100 \mathrm{ml})$ and for values above $8 \mathrm{mmol} / 1, \pm 1.37 \mathrm{mmol} / 1( \pm 24 \cdot 7 \mathrm{mg} / 100 \mathrm{ml})$ $(\mathrm{n}=56$; mean $10.8 \mathrm{mmol} / \mathrm{l}-195 \mathrm{mg} / 100 \mathrm{ml}$ ).

Other collectors-Simple capillary tubes proved too fragile for general use. The Sarstedt "flask" capillary tube and "milking" blood 
into a wide-mouthed tube were too messy for routine use. In all these methods it is difficult to ensure mixing of the blood with the fluoride to prevent glycolysis. The Unopettes were highly satisfactory when used by technicians $(r=0.94$ compared with results of direct plasma glucose assay) and some patients; but most patients had difficulty in transferring the blood to the diluent in the container, and there was no means of determining whether the capillary tube had been insufficiently filled with blood or some blood or diluent had been spilt.

\section{CLINICAL STUDIES}

The mean fasting plasma glucose concentration in all 84 diabetic patients was $8 \mathrm{mmol} / 1(144 \mathrm{mg} / 100 \mathrm{ml})$; in 44 of them the value exceeded $6 \mathrm{mmol} / \mathrm{l}(108 \mathrm{mg} / 100 \mathrm{ml})$. Sixty-three patients managed to take blood samples at home. Of 662 home blood samples, $179\left(27^{\circ}{ }_{0}\right)$ Reflotest strips. had to be rejected because the drops of blood had not been correctly applied, and $53(8 \%)$ collector bottles contained less than $10 \mathrm{ul}$ of blood. In each case inadequate results probably arose in part from the use of both methods on the same occasion.

The table shows the day-to-day variation of the estimated fasting plasma glucose concentration in patients with values below $8 \mathrm{mmol} / 1$.

Day-to-day variation ( $\pm 1 S D$ ) of fasting plasma glucose concentrations $(\mathrm{mmol} / \mathrm{l})$ in patients with values below $8 \mathrm{mmol} / \mathrm{l}(144 \mathrm{mg} / 100 \mathrm{ml})$

\begin{tabular}{ll|c|c|c}
\hline & Clinic sampling & Home sampling & $\begin{array}{c}\text { Comparison of } \\
\text { home sampling } \\
\text { with clinic } \\
\text { venous fluoride }\end{array}$ \\
\hline $\begin{array}{ll}\text { Fluoride.. } \\
\text { Reflotest.. } \\
\text { Collector }\end{array}$ & $\cdots$ & $\begin{array}{l} \pm 0.77(\mathrm{n}=35) \\
\pm 0.80(\mathrm{n}=36) \\
\pm 0.93(\mathrm{n}=40)\end{array}$ & $\begin{array}{l} \pm 0.73(\mathrm{n}=70) \\
0.91(\mathrm{n}=96)\end{array}$ & $\begin{array}{c}0.92(\mathrm{n}=70 \\
0.85(\mathrm{n}=85\end{array}$ \\
\hline
\end{tabular}

Conversion: SI to traditional units-Plasma glucose: $1 \mathrm{mmol} / 1 \approx 18 \mathrm{mg} / 100 \mathrm{ml}$.

There was little difference in precision between the methods. The disparity between home Reflotest and clinic fluoride results was slightly greater than would be expected from the precision of each, probably reflecting the inability of some patients to time accurately the contact of blood on the Reflotest strip. Figure 3 shows the fasting plasma glucose concentrations measured in collector bottle samples at home and in the clinic, the latter being a mean of $0.4 \mathrm{mmol} / 1$ $(7 \cdot 2 \mathrm{mg} / 100 \mathrm{ml})$ higher than those taken at home $(P<0.005)$.

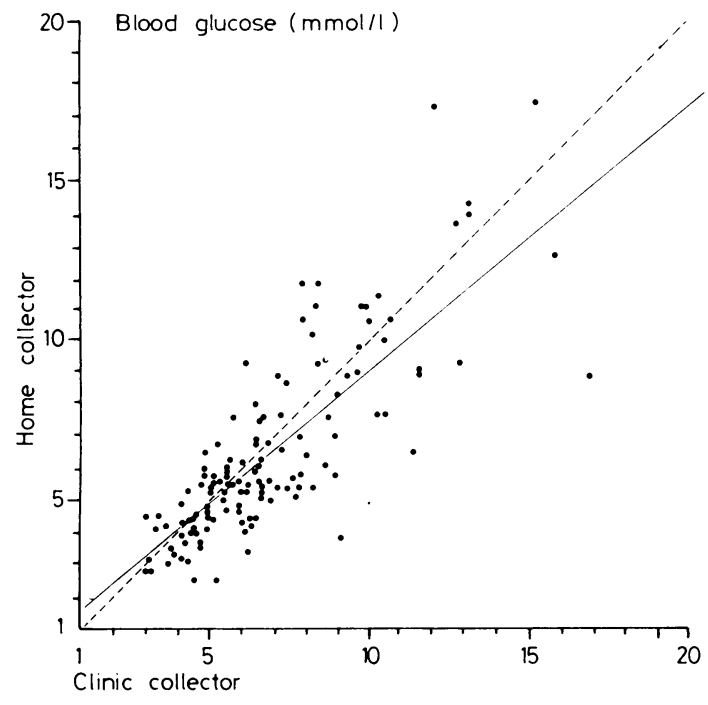

FIG 3-Comparison between fasting plasma glucose concentrations measured in blood taken into vacuum collector bottles either at home by patient or in general practice clinic $(r=0.89)$. For values below $8 \mathrm{mmol} / 1$ clinic value was mean of $0.4 \mathrm{mmol} / 1$ higher than samples taken at home. (Blood glucose: $1 \mathrm{mmol} / 1 \approx 18 \mathrm{mg} / 100 \mathrm{ml}$.)

\section{Discussion}

These simple methods of blood collection and transport provide sufficiently accurate results to permit clinical decisions on diabetic control. The changes in plasma glucose concentrations with treatment of diabetes are much greater than the small differences arising from storage of the Reflotest strips or from individual variation in plasma sodium concentration or packed cell volume affecting collector bottle results. The $\overline{\bar{B}}$ Reflotest method obviates the need for assessment in a laboratory, although the patient must be reliable enough to time accurately a drop of blood on the strip for one minute. The collector bottle has the advantage that the result is independent. of the patient's skill. Both methods are more acceptable to patients than taking blood samples in the available capillary of tubes, which tend to be either messy or ton complicated for $\vec{\circ}$ general use.

Many patients with maturity-onset diabetes who are thought $\vec{\omega}$ to be "well controlled" because of the absence of glycosuria $\frac{\rho}{\partial}$ may have pronounced basal hyperglycaemia. Monitoring the 3 fasting plasma glucose concentration would permit better i control. The day-to-day variation measured by any of these $\stackrel{S}{\vec{\omega}}$ methods exceeded the $0.3 \mathrm{mmol} / 1(+5.4 \mathrm{mg} / 100 \mathrm{ml})( \pm 1 \mathrm{SD}) \stackrel{\vec{v}}{\omega}$ of mild diabetes under strictly basal conditions. ' This was prob- ir ably due to varying "stress" factors, including exercise, on \&ै different mornings; but there was not a marked difference in fasting plasma glucose concentration between samples taken at $N$ home and in the clinic.

The day-to-day variation was sufficiently small, whether assessed in the clinic or at home by the transportable methods, for lowering the fasting plasma glucose to below $6 \mathrm{mmol} / \mathrm{l}$ $(108 \mathrm{mg} / 100 \mathrm{ml})$ to be a reasonable aim in patients with maturityonset diabetes. In practice these patients can be most easily monitored at general practice surgeries, the fasting plasma glucose concentration being measured in a Reflomat. For patients unable to attend, however, either of the transportable methods may be used. Equally, these methods are suitable for monitoring control throughout the day in insulin-dependent diabetics during their normal routine.

We are grateful to Mr E Bown and Mrs R Mullins for skilled technical work; to the general practitioners of Beaumont Street, Berinsfield, and East Oxford Health Centres for their help, and Dr T D R Hockaday and Dr A J Tulloch for encouragement; and to Boehringer Mannheim and the Oxford Regional Health Authority for grants.

Requests for reprints should be addressed to Dr R C Turner.

\section{References}

1 Holman, R R, and Turner, R C, Lancet, 1977, 1, 469.

${ }^{2}$ Holman, R R, and Turner, R C, Metabolism, 1978, 27, 539.

3 Walford, S, et al, Lancei, 1978, 1, 732.

4 Sonksen, P H, Judd, S L, and Lowy, C, Lancet, 1978, 1, 729.

5 Drabkin, D L, Fournal of Biological Chemistry, 1950, 185, 231.

6 Welt, L G, Transactions of the Association of American Physicians, 1964, 77, 169.

7 Holman, R R, and Turner, R C, submitted for publication.

(Accepted 5 fuly 1978)

ONE HUNDRED YEARS AGO An inquest was lately held at Wycombe Marsh, High Wycombe, on the body of a child named F E Rumbelow, aged 7. The deceased was bitten by a black and tan terrier dog, and some days later was taken ill at school. A wound on her leg, caused by the bite, was very much inflamed, and her mother 8 applied cold water bandages. On the following morning, the child said the wound was not so painful, but complained of soreness in the throat. She gradually got worse from that time, and died displaying all the symptoms of hydrophobia. The deputy-coroner (Mr G A Charsley) hoped the Chancellor of the Exchequer would take some restrictive steps regarding dogs during next session. (British Medical fournal, 1878.) 